\title{
The prevalence of Strongyloides stercoralis infection in rural population of Bali: A preliminary study
}

\author{
Dewa Putu Widjana, Putu Sutisna
}

\begin{abstract}
Abstrak
Pada bulan Maret sampai September 1992 dilakukan studi potong lintang di empat desa yang berbeda iklim-geologis di Bali untuk mengetahui prevalens infeksi Strongyloides stercoralis yang berkaitan dengan umur, gender dan kondisi iklim-geologis. Jumlah sampel sebanyak 2880 orang yang dipilih secara random stratifikasi bertahap berdasarkan umur dan gender. Larva Strongyloides pada sampel tinja diidentifikasi dengan tehnik modifikasi Harada Mori biakan tinja. Hasil menunjukkan bahwa prevalensi infeksi Strongyloides sebesar 1,6\%; prevalens pada laki-laki sebesar 1,2\% dan pada perempuan sebesar 2,1\%, akan tetapi tidak terdapat perbedaan secara statistik menurut gender. Menurut umur juga tidak terdapat perbedaan secara bermakna. Prevalensi tertinggi (2.4\%) terdapat pada anak-anak berumur 7-12 tahun, diikuti oleh yang berumur tujuh tahun atau kurang (1.6\%), 18 tahun atau lebih (1,6\%), dan 13-18 tahun (0.6\%). Prevalens infeksi Strongyloides berkaitan dengan iklim-geologis. Prevalens infeksi Strongyloides tertinggi terdapat pada daerah tinggi dan basah (3,3\%), dikuti daerah rendah dan basah (1.5\%), daerah tinggi dan kering dan (1,0\%), dan terendah di daerah rendah dan kering (0.9\%). Dapat disimpulkan bahwa prevalens infeksi Strongyloides stercoralis di Bali rendah dan berkaitan dengan jenis iklim dan geologis, akan tetapi tidak ditemukan kaitan dengan gender dan golongan umur. (Med J Indones 2001; 10: 174-7)
\end{abstract}

\begin{abstract}
A cross-sectional study was carried out from March until September 1992 in 4 different geo-climatic rural villages in Bali to assess the prevalence of Strongyloides stercoralis infection related to age, gender and geo-climatic condition. The number of selected samples using multistage stratified random sampling based on age and gender was 2880. Strongyloides larvae in stool samples were identified by modified Harada Mori fecal culture technique. The results showed that the overall prevalence of Strongyloides infection was $1.6 \%$; the prevalence in male was $1.2 \%$ and in female was $2.1 \%$, however the gender difference was not statistically significant. In term of age, there was no statistically significant difference. The highest prevalence $(2.4 \%)$ was found among 7 - 12 years children, followed by aged 7 years or less (1.6\%), 18 years or over (1.6\%), and 13-18 years $(0.6 \%)$. The prevalence of Strongyloides infection related to geo-climatic conditions was significantly difference. The highest prevalence of Strongyloides infection was at wet highland $(3.3 \%)$, followed by wet lowland (1.5\%), dry highland (1.0\%), and dry lowland (0.9\%). In conclusion, the prevalence of Strongyloides stercoralis infection in Bali was very low prevalence of Strongyloides infection was highly related to geo-climatic type of area, but not to gender and age groups. (Med J Indones 2001; 10: 174-7)
\end{abstract}

Keywords: Strongyloides stercoralis, geo-climatic condition, modified Harada Mori technique, rural population, Bali

Strongyloides stercoralis (S. stercoralis) is one of the intestinal nematodes of the soil-transmitted helminth group, the ova or larvae become infective after some time in the soil.' In developing countries, the number of surveys on $S$. stercoralis is much smaller than the number of surveys on other soil-transmitted helminth. This may be related to the fact that Strongyloides infection is rare in these countries compared to Ascaris, Trichuris and hookworm infection. ${ }^{2}$ In some parts of the world, Strongyloides infection tends to

Department of Parasitology, Faculty of Medicine, Udayana University, Denpasar, Bali, Indonesia parallel hookworm infection, both in its geographical distribution and incidence. In some countries such as Brazil and Columbia, Strongyloides infection is more prevalent and hence more serious disease than hookworm infection, with a prevalence rate of $58 \%$ and $20 \%$ respectively. In other countries, however, prevalence of $S$. stercoralis is much lower than hookworm infection. ${ }^{2}$ Whatever the level of prevalence, the life of $S$. stercoralis is very much similar to that of hookworm i.e. it is highly dependent on soil, sanitation and climatic condition. ${ }^{6}$

In the Philippines the prevalence of $S$. stercoralis infection was $2.27 \%{ }^{2}$ The prevalence of $S$. stercoralis 
in some areas in Thailand and among Cambodian refugees in Thailand was $0.43 \%$ and $0.88 \%$ respectively. ${ }^{3,4}$ In Indonesia a very low prevalence of Strongyloides infection was reported in 1989 than the prevalence in 1956. In 1989 the prevalence was 9.4\% among hospitalized patients and $16.3 \%$ among autopsies.

S. stercoralis is an opportunistic parasite which becomes highy pathogenic in immune compromised patients such as among HIV patients, T cell leukemia patients, and in chronic diseases and after prolonged immunity-suppressing medication. In these cases the intestinal barrier decreases sharply resulting in massive invasion of L3 larvae which leads to hyperinfection and severe sepsis, which may cause death. ${ }^{7,8}$ As the incidence of HIV infection is increasing from time to time, Strongyloides infection is becoming more and more important as a cause of health problems.

The present study aimed to identify the prevalence of Strongyloides infection in the rural population of Bali and to describe its relationship to age, gender and geoclimatic factors. The baseline data gathered from this study may be useful for the purpose of developing a control program against the infection.

\section{METHODS}

This cross-sectional study was carried out during dry season from March to September 1992. The study was conducted in four villages, representing the different geoclimatic types of Bali Island: ${ }^{9}$ (1) The village of Belumbang, in Sub-district of Kerambitan, $25 \mathrm{~km}$ west of Denpasar, capital of Bali. It has an elevation of 0 to $500 \mathrm{~m}$ above sea level with ecosystem basis of rice-fields, well irrigated all year around. The soil is of yellowish lactose type, consisted of volcanic debris. Average annual rainfall is $1,726 \mathrm{~mm}$ with 7 months of wet and one month of dry season. The average humidity and temperature are $75.9 \%$ and $27.4^{\circ}$ Celsius. This village represents wet lowland area. (2) The village of Baturiti, in Sub-district of Baturiti represents wet highland area. It lies $50 \mathrm{~km}$ north of Denpasar with an elevation of 500-1000 m above sea level. Its ecosystem basis is mostly ricefields, and the soil is of brown andotol type. Average annual rainfall is $2,857 \mathrm{~mm}$ with no months of dry season. The average humidity and temperature are $84.1 \%$ and $21.7 \%$ Celsius respectively. (3) The village of Kubutambahan, in Sub-district of Kubutambahan represents dry lowland area, located $100 \mathrm{~km}$ north of
Denpasar, at an elevation of 0-500 $\mathrm{m}$ above sea level. Its ecosystem basis is field-crops, no rice-fields, with soil of brown regosol type. Average annual rainfall of $980 \mathrm{~mm}$, each with 4 months wet season and dry season. The averag temperature is $28.0^{\circ}$ Celsius. (4) The village of Batur Selatan at Sub-district of Kintamani represents dry highland area. It lies $70 \mathrm{~km}$ northeast of Denpasar, with an elevation of $1000 \mathrm{~m}$ above sea level. Its ecosystem basis is field-crops with no rice-fields, its soil is of humid regosol type. Average annual rainfall is $2,129 \mathrm{~mm}$ with 6 months of wet season and 5 months of dry season. The average humidity and temperature are $86.5 \%$ and $18.7^{\circ}$ Celsius respectively.

The selected number of population sample was 2,880 persons, selected by multistage stratified random sampling technique, based on age and gender. Age was taken as one of the independent variable as it was known in hookworm infection that age was a contributing factor to the event and level of infection. ${ }^{10}$ While gender was taken as an independent variable because of the different socio-behaviors of men and women that are closely related to infection. ${ }^{11}$

The presence of S. stercoralis larvae in stool of the study subjects were determined by modified Harada Mori fecal culture technique. All cultures and their assessment were done entirely in the laboratory of the Department of Parasitology, Faculty of Medicine, Udayana University, by 6 well-trained staff of the department (senior doctors and parasitologists). Before stools were collected from the selected individuals, we conducted a meeting with the local formal and informal leaders as well as the local field workers of each of the six selected villages. In the meeting we explained about the objectives and usefulness of the study, collection of stool samples from selected individuals, laboratory examinations done, and other related things. We asked the leaders and field workers to convey all the information to each of the study subjects.

All data collected were analyzed descriptively and analytically using chi-square test.

\section{RESULTS}

Of the selected 2880 samples, 2410 could be recovered and of these 2394 could be completely analyzed (16 were excluded due to incomplete data). 
Table 1 shows that out of 2394 stool samples examined, and 39 were positive for S. stercoralis larvae, giving an overall prevalence rate of $1.6 \%$. The prevalence rate in male was $1.2 \%$ and in female was $2.1 \%$. However, the difference was not statistically significant.

Table 1. Strongyloides stercoralis infection and number of stool examined by gender, age group, and geoclimatic type

\begin{tabular}{lcccc}
\hline & $\begin{array}{c}\text { S. stercoralis } \\
\text { infection } \\
\text { positive }\end{array}$ & $\begin{array}{c}\text { Number } \\
\text { of } \\
\text { examined }\end{array}$ & $\begin{array}{c}\text { Pre- } \\
\text { valence } \\
(\%)\end{array}$ & p \\
\hline Gender & 9 & 1199 & 1.2 & 0.074 \\
Male & 18 & $1 ! 95$ & 2.1 & \\
Fernale & & & & 0.108 \\
Age group & 8 & 504 & 1.6 & \\
7 years or lower & 17 & 699 & 2.4 & \\
7 -12 years & 3 & 496 & 0.6 & \\
13-18 years & 11 & 695 & 1.6 & \\
18 years or & & & & \\
over & & & & \\
Geo-climatic & 9 & 614 & 1.5 & \\
type & 18 & 539 & 3.3 & \\
Wet lowland & 7 & 692 & 1.0 & \\
Wet highland & 5 & 549 & 0.9 & \\
Dry highland & & & & \\
Dry lowland & & & & \\
\hline
\end{tabular}

Based on age groups, the highest prevalence $(2.4 \%)$ was among 7-12 years children, followed by 7 years or lower (1.6\%), 18 years or more (1.6\%), and 13-18 years $(0.6 \%)$. The prevalence differences were not statistically significant.

The prevalence of $S$. stercoralis infection related to geo-climatic conditions was significantly difference. The highest prevalence of $S$. stercoralis infections were at wet highland (3.3\%), followed by wet lowland $(1.5 \%)$, dry highland $(1.0 \%)$, and dry lowland $(0.9 \%)$.

\section{DISCUSSION}

In this study we did not specifically related environmental sanitation with the level of infection in the four different geo climatic areas, as in a previous study on hookworm infection on Bali we found no significant differences of sanitation condition in the four geo climatic areas (personal communication).

The overall prevalence of $S$. stercoralis infection in the rural population of Bali was $1.6 \%$. In Surabaya the prevalence was found to be $2-3 \%$. $^{7}$ In the Philippines the prevalence of $S$. stercoralis infection was $2.27 \%{ }^{2}$ Preuksaraj et al. ${ }^{3}$ (1981) reported the prevalence of $0.43 \%$ in Thailand; and among Cambodian refugees in Thailand the prevalence was $0.88 \%$. ${ }^{4}$ The prevalence of $S$. stercoralis infection in Bali was very low compared to the prevalence of hookworm infection. There is no doubt that the prevalence rate of $S$. stercoralis infection is much lower than hookworm infection almost anywhere, except probably in Brazil and Columbia. This is rather strange if we consider that $S$. stercoralis females are more prolific than hookworm females. In addition, the presence of freeliving generation of $S$. stercoralis in soil, which does not occur in hookworm, would theoretically increase the number of larvae in the soil. There are two factors which can explain the difference. Firstly, the first stage larvae in feces may not be as resistant as hookworm eggs. Secondly, the filariform larvae of $S$. stercoralis may be more sensitive to drying, excess of moisture or mark change in temperature, hence a much shorter life span than hookworm filariform larvae. ${ }^{2}$

By age group and gender, the prevalence of $S$. stercoralis infection showed a controversial result. In this study the prevalence in female was higher then in male and prevalence among 7-12 years children were also higher compared to other age groups. This result agrees with Cabrera foindings, ${ }^{2}$ but contradicting with the report of Belding. ${ }^{6}$ According to geo climatic type of area, significant highest prevalence of $S$. stercoralis infection was found in wet highland, followed by wet lowland, dry highland and dry lowland. The explanation of this is that prevalence of $S$. stercoralis infection is parallel with prevalence of hookworm infection. ${ }^{2,8,12}$ This may lead us to a conclusion that geo-climatic factors, such as soil textures, farming ecosystem, temperature, humidity and rainfall essentially influence the infection of $S$. stercoralis.

In conclusion, the prevalence of Strongyloides infection in the rural population of Bali was very low $(1.6 \%)$ compared to the prevalence of hookworm infection. The highest prevalence of Strongyloides infection in Bali was at wet highland area. It was significantly related to geo-climatic types of areas, but it was not related to gender and age groups. It is recommended that a control action be undertaken with priority given to people in the wet highland areas of Bali. 


\section{Acknowledgments}

We would like to thank the International Development Research Center (IDRC) Canada, for providing a grant aid for this study. Thanks are also due to Dr. Pandu Wijeyeratne for his assistance during the preparation of the study. We are indebted to Drs. Nengah Kapti, Luh Ariwati, Nyoman Wartana and Ketut Ngurah, for their assistance in several parts of the study. Lastly, we thank the village leaders, field workers and all subjects for their participating in this study.

\section{REFERENCES}

1. Setasubon P. soil-transmitted helminthiasis. Proceeding of the 25th Anniversary of the Faculty of Tropical Medicine, Mahidol University, Bangkok, Thailand; 1986:148-51.

2. Cabrera BD. Prevalence of Strongyloides stercoralis infection in selected areas in the Philippines using a modified Harada-Mori culture technique. In: Collected papers on the control of soil-transmitted helminthiases. APCO Vol. II; 1983:19-26.

3. Preuksaraj S, Jeradit C, Sathitayathai S, Seedonrusmi A. studies on prevalence and intensity of intestinal helminthic infections in the rural population of Thailand 1980-1981. In: Collected papers on the control of soiltransmitted helminthiases. APCO Vol. II; 1983:54-8.
4. Keittivuti B, D'agnes T, Keittivuti A, Viravaidya M. The Prevalence of Parasitic Infection among Cambodian Refugees Residing in Ban-Kaeng Holding Center, Prachinburi Province Thailand. In: Collected Papers on the Control of Soil-transmitted Helminthiases. APCO Vol. II; 1983: 59 - 65 .

5. Oemijati S. The current situation of parasitic infection in Indonesia. Bulletin of Hlth Studies. 1983;17:12-21.

6. Belding DL. Textbook of parasitology. $2^{\text {nd }}$ ed. New York: Appleton-Century-Crofts; 1965.

7. Buditjahjono DH. Strongyloidiasis in global. Proceedings of 8th Regional Meeting of Medical Parasitology, Denpasar, Bali; 1995.

8. Tanaka, H. Strongyloides infection. In: Goldsmith R, Heyneman D, editors. Tropical medicine and parasitology. Appleton \& Lange; 1989:368-73.

9. Suweta IGP. Economic loss due to hepatic worm among cattle as interaction implication in living environmental at agriculture ecosystem in Bali Island. [dissertation]. Bandung: University of Padjadjaran; 1982.

10. Anderson RM. The population dynamic and epidemiology of intestinal nematode infection. Trans R Soc Trop Med Hyg 1986;80:686-96.

11. Bakta IM, Widjana DP, Sutisna P. Some epidemiological aspects of hookworm infection among the rural population of Bali, Indonesia. Southeast Asian J Trop Med Pub Hlth 1993;24:87-93.

12. Grove DL. Strongyloides infection. In: Warren SK, Mahmoud AAF, editors. Tropical and geographical medicine. New York: McGraw-Hill Book Co; 1986:373-9. 